\title{
The seasonal influence on airborne dust and endotoxin concentrations in a laying hen house
}

\author{
Kristina Matković1 ${ }^{\star}$, Ljerka Prester², Tatjana Orct² ${ }^{2}$ Jelena Macan², \\ Veda M. Varnai ${ }^{2}$, Danijel Marušićc ${ }^{3}$, Mario Ostović1, Željko Pavičić1, \\ and Marija Vučemilo ${ }^{4}$ \\ ${ }^{I}$ Department of Animal Hygiene, Behaviour and Welfare, Faculty of Veterinary Medicine, University of \\ Zagreb, Zagreb, Croatia \\ ${ }_{2}^{2}$ Institute of Medical Research and Occupational Health, Zagreb, Croatia \\ ${ }^{3}$ The County Prefect Office, Slavonski Brod, Croatia \\ ${ }^{4}$ Jakova Gotovca 13, Zagreb, Croatia
}

MATKOVIĆ, K., LJ. PRESTER, T. ORCT, J. MACAN, V. M. VARNAI, D. MARUŠIĆ, M. OSTOVIĆ, Ž. PAVIČIĆ, M. VUČ́EMILO: The seasonal influence on airborne dust and endotoxin concentrations in a laying hen house. Vet. arhiv 87, 597-605, 2017.

\section{ABSTRACT}

In the present study, air quality in a cage-housed laying hen house was investigated throughout the seasons by assessing dust and endotoxin concentrations. Measurements were done twice a month during the 1-year production cycle. The mean levels of dust and endotoxins ranged from $0.60 \mathrm{mg} / \mathrm{m}^{3}$ in May to $2.83 \mathrm{mg} / \mathrm{m}^{3}$ in November, and from $203.15 \mathrm{EU} / \mathrm{m}^{3}$ in August to $745.53 \mathrm{EU} / \mathrm{m}^{3}$ in April. Significantly higher concentrations of dust and endotoxins in the poultry house were determined in the autumn and winter seasons, and endotoxins in the spring season as well, compared to the summer $(\mathrm{P}<0.05$ all $)$. The results suggested that the cooler periods of the year pose a greater risk for the welfare and performance of laying hens, but also for the health of humans working in these settings in terms of the levels of airborne dust and endotoxins.

Key words: air quality, dust, endotoxins, poultry, season

\section{Introduction}

Livestock housing systems, for poultry in particular, generate and emit large amounts of dust (CAMBRA-LÓPEZ et al., 2009; JUST et al., 2009; DAVID et al., 2015), which includes all solid particles in a gas without flow that deposit slower than has been established

\footnotetext{
${ }^{*}$ Corresponding author:

Kristina Matković, Associate Professor, PhD, DVM, Department of Animal Hygiene, Behaviour and Welfare, Faculty of Veterinary Medicine, University of Zagreb, Heinzelova 55, HR-10000 Zagreb, Croatia, Phone: +385 12390 292, Fax: +385 1 2441 390, E-mail: kmatkov@vef.hr
} 
by classic laws on fall. The health effects of dust particles on animals depend on the nature of the particles (organic, inorganic and nonspecific), the compounds the particles are carrying, and the diameter of the particles (OSTOVIĆ et al., 2009). High dust levels may irritate the mucous membranes of the respiratory system, cause inflammation and allergic reactions, and lower animal resistance. Dust particles are often carriers of pathogenic agents, harmful stable gases and unpleasant odours (SEEDORF and HARTUNG, 2002; MATKOVIĆ et al., 2012). The sources of dust in poultry houses are food, litter, the animals themselves, especially their feathers and manure, microorganisms and endotoxins (KIRYCHUK et al., 2006; VUČEMILO et al., 2008).

Endotoxins are a component of the cell wall of gram-negative bacteria, which are ubiquitous in the environment and can be found in the air, soil, water, dust, as well as in industrial and agricultural facilities, including animal housings (RYLANDER, 2002). Nevertheless, the share of gram-negative bacteria in the total number of airborne microorganisms is relatively small, probably because of their sensitivity to various environmental factors (MATKOVIĆ et al., 2012). Endotoxins are composed of lipopolysaccharide thermo-stable proteins and phospholipids (MADSEN, 2006). They are liberated into the environment after lysis of the cell wall, but may also be liberated during bacterial multiplication. After chronic exposure, even in low concentrations, endotoxins may cause strong inflammatory and allergic reactions, and impair respiratory system function (VARNAI et al., 2004; HUNEAU-SALAÜN et al., 2011).

Following a previous study on airborne bacteria and fungi in a laying-hen house over the 1-year production cycle (MATKOVIĆ et al., 2013), this study reports on dust and endotoxin concentrations throughout the seasons.

\section{Materials and methods}

The study was conducted in a poultry house in the central part of Croatia, during all seasons, i.e. 12 months, by observing the 1-year production cycle of 17,200 cage-housed Shaver hybrid laying hens. For a description of the house and housing system, including the measurements of other previously reported microclimate parameters, see the study by MATKOVIĆ et al. (2013).

The dust was sampled using SKC pumps (SKC Ltd., Blandford Forum, UK) and filters (Whatman International Ltd., Maidstone, UK), with an air flow rate of $4.0 \mathrm{~L} / \mathrm{min}$, over a 4-hour period twice a month, at two sites inside the house. Total dust concentration in the air $\left(\mathrm{mg} / \mathrm{m}^{3}\right)$ was measured by weighing the filters before and after sampling, in a controlled laboratory, at an air temperature of $22{ }^{\circ} \mathrm{C}$ and relative humidity of $45 \%$ ( \pm $5 \%$ ). Sampled filters were stored at $-20^{\circ} \mathrm{C}$ until endotoxin analysis.

Pyrogen free glass and microplates (Greiner Labortechnik GmbH, Germany) were used for endotoxin determination. The filters, including controls, were extracted in $5 \mathrm{~mL}$ 
of distilled reagent water for two hours at room temperature. Extracts were centrifuged at $3000 \mathrm{rpm}$ for 10 minutes. Supernatants were placed into fireproof plates at $75{ }^{\circ} \mathrm{C}$ for 20 minutes before analyses, to avoid possible interference. Endotoxin concentration was determined by the Limulus Amebocyte Lysate (LAL) test reported elsewhere (VARNAI et al., 2004). A commercial kit with Endocrom (Charles River Endosafe, USA) was used, including LAL reagent (lyophilized), standard (E. coli standard control endotoxin), buffer solution and LAL reagent water.

A standard curve was created according to the endotoxin standard of $24 \mathrm{EU} / \mathrm{mL}$ diluted with the LAL reagent water, which was also used for multiple extract dilutions (1:25 to $1: 200)$. The LAL analysis was conducted at $37^{\circ} \mathrm{C}$. Optical density of $405 \mathrm{~nm}$ was determined on a Personal Lab microplate analyser (Iason, Graz, Austria). Endotoxin concentrations were determined using the standard curve, proportionally to colour change. Results were expressed as Endotoxin Units per $1 \mathrm{~m}^{3}$ of air $\left(\mathrm{EU} / \mathrm{m}^{3}\right)$. Each sample was measured in duplicate. Controls had very small endotoxin concentrations. Analysis efficacy was $95 \%$. The lower detection limit was $0.008 \mathrm{EU} / \mathrm{mL}$.

Statistical analysis was performed using Statistica v.10 (StatSoft Inc., 2011) software. Data were analysed using ANOVA Repeated Measures and the Tukey HSD test for post hoc analysis. Correlations between the parameters were assessed by a correlation rank coefficient, ranging from -1 to +1 .

\section{Results}

The mean values of dust ranged from $0.60 \mathrm{mg} / \mathrm{m}^{3}$ in May to $2.83 \mathrm{mg} / \mathrm{m}^{3}$ in November. The mean endotoxin concentrations ranged from $203.15 \mathrm{EU} / \mathrm{m}^{3}$ in August to $745.53 \mathrm{EU} /$ $\mathrm{m}^{3}$ in April (Table 1).

The mean dust and endotoxin concentrations per season are shown in Figs 1 and 2, respectively. The lowest dust concentration recorded in summer significantly differed $(\mathrm{P}<0.05)$ from the autumn and winter levels (Fig. 1). The endotoxin concentration was also lowest in summer, differing significantly $(\mathrm{P}<0.05)$ from spring, autumn and winter concentrations (Fig. 2).

Correlations between the dust and endotoxin concentrations, and other microclimate parameters observed (MATKOVIĆ et al., 2013) by months are presented in Table 2. A significant influence $(\mathrm{P}<0.05)$ of ammonia concentrations on dust and endotoxin concentrations, as well as of air temperature on endotoxin concentrations was recorded in February. In March, there was a significant correlation $(\mathrm{P}<0.05)$ between air velocity and dust and endotoxin concentrations. Carbon dioxide concentrations had a significant impact on dust levels in April, air temperature and ammonia in June, and air temperature and air velocity in July $(\mathrm{P}<0.05$ all). The study results also revealed the significant influence $(\mathrm{P}<0.05)$ of air temperature, air velocity and ammonia on dust and 
K. Matković et al.: Airborne dust and endotoxins in poultry house

endotoxin concentrations in August. In September, air temperature, relative humidity and ammonia concentrations had a significant impact $(\mathrm{P}<0.05)$ on endotoxin concentrations. In November, the dust concentration was significantly influenced $(\mathrm{P}<0.05)$ by relative humidity and ammonia.

Table 1. Mean levels of airborne dust and endotoxins in a laying hen house during a 1-year production cycle

\begin{tabular}{|c|l|c|c|}
\hline \multirow{4}{*}{ Season } & \multirow{2}{*}{ Month } & Dust $\left(\mathrm{mg} / \mathrm{m}^{3}\right)$ & \multicolumn{2}{|c|}{ Endotoxins $\left(\mathrm{EU} / \mathrm{m}^{3}\right)$} \\
\cline { 2 - 4 } & March & $2.00 \pm 0.81$ & \multicolumn{2}{|c|}{ Mean $\pm \mathrm{SD}$} \\
\hline \multirow{3}{*}{ Spring } & April & $1.35 \pm 0.42$ & $797.08 \pm 316.78$ \\
\cline { 2 - 4 } & May & $0.60 \pm 0.42$ & $214.08 \pm 50.86$ \\
\cline { 2 - 4 } & June & $0.65 \pm 0.33$ & $224.80 \pm 101.16$ \\
\hline \multirow{3}{*}{ Summer } & July & $1.08 \pm 0.38$ & $251.53 \pm 95.25$ \\
\cline { 2 - 4 } & August & $0.93 \pm 0.51$ & $203.15 \pm 36.45$ \\
\cline { 2 - 4 } & September & $0.83 \pm 0.36$ & $352.85 \pm 98.26$ \\
\hline \multirow{3}{*}{ Winter } & October & $1.73 \pm 0.51$ & $439.73 \pm 156.96$ \\
\cline { 2 - 4 } & November & $2.83 \pm 0.86$ & $449.75 \pm 150.39$ \\
\cline { 2 - 4 } & December & $1.65 \pm 0.74$ & $533.28 \pm 248.99$ \\
\cline { 2 - 4 } & January & $0.93 \pm 0.29$ & $527.00 \pm 125.33$ \\
\cline { 2 - 4 } & February & $2.70 \pm 0.32$ & $422.13 \pm 91.10$ \\
\hline
\end{tabular}

$\mathrm{n}=2$ measurements per month

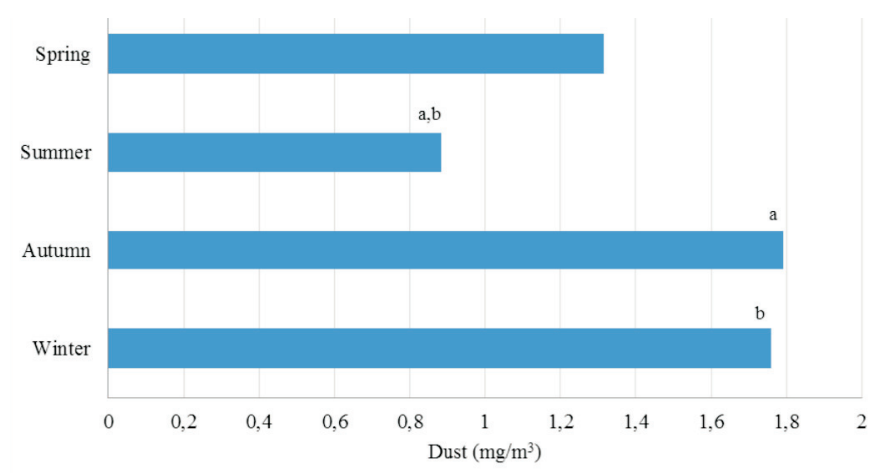

Fig. 1. Mean dust concentrations according to seasons

${ }^{\mathrm{a}, \mathrm{b}}$ Mean values marked with the same letter in superscript are statistically significantly different $(\mathrm{P}<0.05)$ 
K. Matković et al.: Airborne dust and endotoxins in poultry house

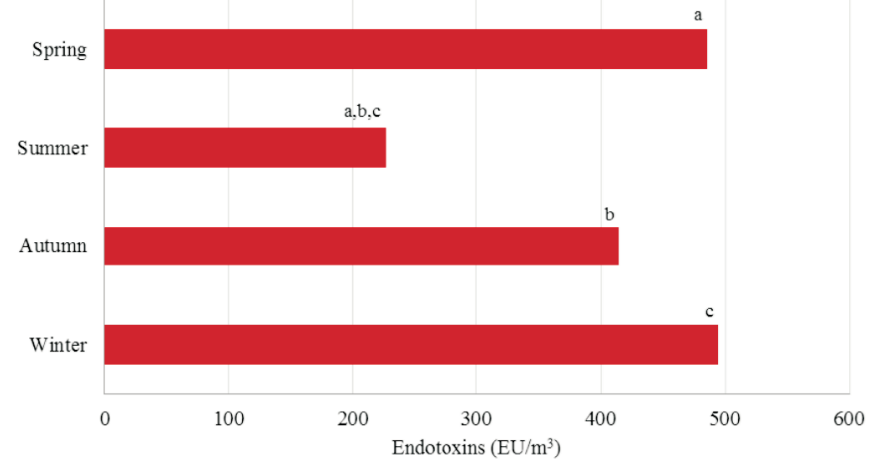

Fig. 2. Mean endotoxin concentrations according to seasons

a,b,c Mean values marked with the same letter in superscript are statistically significantly different $(\mathrm{P}<0.05)$

Table 2. Statistically significant $(\mathrm{P}<0.05)$ correlations recorded between the parameters during the production year

\begin{tabular}{|c|c|c|}
\hline Month & Correlated parameters & Correlation coefficient \\
\hline \multirow{3}{*}{ February } & $\mathrm{NH}_{3} /$ dust & 0.64 \\
\hline & t/endotoxins & -0.64 \\
\hline & $\mathrm{NH}_{3} /$ endotoxins & -0.65 \\
\hline \multirow{2}{*}{ March } & w/dust & 0.68 \\
\hline & w/endotoxins & 0.70 \\
\hline April & $\mathrm{CO}_{2} /$ dust & 0.67 \\
\hline \multirow{2}{*}{ June } & t/dust & 0.74 \\
\hline & $\mathrm{NH}_{3} /$ dust & 0.63 \\
\hline \multirow{2}{*}{ July } & t/dust & 0.92 \\
\hline & w/dust & -0.72 \\
\hline \multirow{6}{*}{ August } & t/dust & 0.72 \\
\hline & t/endotoxins & -0.72 \\
\hline & w/dust & -0.69 \\
\hline & w/endotoxins & -0.70 \\
\hline & $\mathrm{NH}_{3} /$ dust & 0.83 \\
\hline & $\mathrm{NH}_{3} /$ endotoxins & 0.83 \\
\hline \multirow{3}{*}{ September } & t/endotoxins & -0.83 \\
\hline & rh/endotoxins & 0.66 \\
\hline & $\mathrm{NH}_{3} /$ endotoxins & -0.74 \\
\hline \multirow{2}{*}{ November } & rh/dust & -0.80 \\
\hline & $\mathrm{NH}_{3} /$ dust & 0.66 \\
\hline
\end{tabular}

$\mathrm{t}$ - air temperature, rh - relative humidity, $\mathrm{w}$ - air velocity, $\mathrm{NH}_{3}$ - ammonia, $\mathrm{CO}_{2}$ - carbon dioxide

Vet. arhiv 87 (5), 597-605, 2017 
K. Matković et al.: Airborne dust and endotoxins in poultry house

\section{Discussion}

Good air quality in livestock houses is necessary for the welfare and performance of the animals, as well as for the health of the humans working in those environments. Air in animal houses is regularly contaminated with various pollutants, such as dust, harmful gases, microorganisms and their components - endotoxins (PRESTER et al., 2010; MATKOVIĆ et al., 2012; VIEGAS et al., 2013). In this study, the influence of season on dust and endotoxin levels in the air of laying-hen housing during the 1-year production cycle was investigated, following a previous study on airborne bacteria and fungi (MATKOVIĆ et al., 2013).

The mean airborne dust concentrations per months, ranging from $0.60 \mathrm{mg} / \mathrm{m}^{3}$ to 2.83 $\mathrm{mg} / \mathrm{m}^{3}$ (Table 1), were in accordance with the results of other studies conducted in houses with cage-housed laying hens (GUARINO et al., 1999; LARSSON et al., 1999; WHYTE, 2002; SALEH et al., 2007), the values of which are lower compared to those recorded in other poultry housing systems (NIELSEN and BREUM, 1995; ELLEN et al., 2000). By comparing the mean dust levels per season, a significantly lower (half) dust concentration $(0.88 \mathrm{mg} /$ $\left.\mathrm{m}^{3}\right)$ was determined in the summer versus the autumn $\left(1.79 \mathrm{mg} / \mathrm{m}^{3}\right)$ and winter seasons $\left(1.76 \mathrm{mg} / \mathrm{m}^{3}\right)$.

Numerous factors affect the level of air pollutants in animal housing systems. These include animal species and category, animal activity, the housing system and density, the housing microclimate, litter quality, the type and method of feeding, hygiene procedures and ventilation (MATKOVIĆ et al., 2006; 2012; VUČEMILO et al., 2007). As shown in Table 2 , in the present study a significant positive correlation between air temperature and dust concentrations, as well as a significant negative correlation between air velocity and dust concentrations, was recorded in the summer months. Therefore, the lower concentrations of dust in the air of the house during warmer compared to cooler seasons (Fig. 1) may be ascribed to increased ventilation during the warmer period (MATKOVIĆ et al., 2013), as was also confirmed by DAVIS and MORISHITA (2005). Accordingly, besides the animal category, dust levels in poultry houses are primarily affected by the type of housing system and ventilation.

In this study, endotoxins were isolated from dust samples, as there is a positive correlation between dust and endotoxin concentrations (DONHAM and CUMRO, 1999). Accordingly, lower concentrations of airborne endotoxins were found in cage-housed laying hen houses than in other systems of poultry rearing (SIMPSON et al., 1999; WHYTE et al., 2001; SEEDORF, 2004; HUNEAU-SALAÜN et al., 2011).

The mean endotoxin concentrations per months ranged from $203.15 \mathrm{EU} / \mathrm{m}^{3}$ to 745.53 $\mathrm{EU} / \mathrm{m}^{3}$ (Table 1) and were at the lower level reported in the literature (LARSSON et al., 1999; SALEH et al., 2007; SCHIERL et al., 2007; HUNEAU-SALAÜN et al., 2011). According to season, the lowest mean endotoxin concentration was determined in the summer $(226.49$ 
$\left.\mathrm{EU} / \mathrm{m}^{3}\right)$, which differed significantly from the levels recorded in the spring $(485.56 \mathrm{EU} /$ $\left.\mathrm{m}^{3}\right)$, autumn $\left(414.11 \mathrm{EU} / \mathrm{m}^{3}\right)$ and winter $\left(494.13 \mathrm{EU} / \mathrm{m}^{3}\right)($ Fig. 2), when air temperatures in the house were lower compared to the summer (MATKOVIĆ et al., 2013). Apart from in the spring, the mean endotoxin concentrations followed the mean dust concentrations (Fig. 1 and 2).

A significant negative correlation was determined between endotoxin concentration and air temperature (Table 2). This finding is in contrast to the report by CARTY et al. (2003), who stated that endotoxin levels are higher at higher temperatures. However, as already mentioned, a positive correlation was found between dust and air temperature (Table 2), and between dust and endotoxin level, except for in the spring (Fig. 1 and 2), indicating that dust and endotoxin concentrations were affected by different factors, as shown in Table 2.

In conclusion, the study results showed airborne dust and endotoxin concentrations in a laying-hen house during the 1-year production cycle to be higher in the cooler seasons, presenting greater risk for their welfare and performance, but also for the health of operators in poultry production of this type.

\section{References}

CAMBRA-LÓPEZ, M., A. WINKEL, J. VAN HARN, N. W. M. OGINK, A. J. A. AARNINK (2009): Ionization for reducing particulate matter emissions from poultry houses. T. ASABE $52,1757-1771$.

CARTY, C. L., U. GEHRING, J. CYRYS, W. BISCHOF, J. HEINRICH (2003): Seasonal variability of endotoxin in ambient fine particulate matter. J. Environ. Monit. 5, 953-958.

DAVID, B., R. O. MOE, V. MICHEL, V. LUND, C. MEJDELL (2015): Air quality in alternative housing systems may have an impact on laying hen welfare. Part I - Dust. Animals (Basel). 5, 495-511.

DAVIS, M., T. Y. MORISHITA (2005): Relative ammonia concentrations, dust concentrations, and presence of Salmonella species and Escherichia coli inside and outside commercial layer facilities. Avian Dis. 49, 30-35.

DONHAM, K. J., D. CUMRO (1999): Setting maximum dust exposure levels for people and animals in livestock facilities. Proceedings of the International Symposium on Dust Control in Animal Production Facilities, 30 May-2 June, Aarhus, Denmark, pp. 93-110.

ELLEN, H. H., R. W. BOTTCHER, E. VON WACHENFELT, H. TAKAI (2000): Dust levels and control methods in poultry houses. J. Agric. Saf. Health. 6, 275-282.

GUARINO, M., A. CAROLI, P. NAVAROTTO (1999): Dust concentration and mortality distribution in an enclosed laying house. T. ASAE. 42, 1127-1134.

HUNEAU-SALAÜN, A., S. LE BOUQUIN, V. BEX-CAPELLE, D. HUONNIC, L. BALAINE, M. T. GUILLAM, F. SQUIZANI, C. SEGALA, V. MICHEL (2011): Endotoxin concentration 


\section{K. Matković et al.: Airborne dust and endotoxins in poultry house}

in poultry houses for laying hens kept in cages or in alternative housing systems. Br. Poult. Sci. 52, 523-530.

JUST, N., C. DUCHAINE, B. SINGH (2009): An aerobiological perspective of dust in cage-housed and floor-housed poultry operations. J. Occup. Med. Toxicol. 4: 13.

KIRYCHUK, S. P., J. A. DOSMAN, S. J. REYNOLDS, P. WILLSON, A. SENTHILSELVAN, J. J. FEDDES, H. L. CLASSEN, W. GUENTER (2006): Total dust and endotoxin in poultry operations: comparison between cage and floor housing and respiratory effects in workers. J. Occup. Environ. Med. 48, 741-748.

LARSSON, B., K. LARSSON, P. MALBERG, L. MARTENSSON, L. PALMBEG (1999): Airway response in native subjects to exposure in poultry houses: comparison between cage rearing and alternative rearing system for laying hens. Am. J. Ind. Med. 35, 142-149.

MADSEN, A. M. (2006): Airborne endotoxin in different background environments and seasons. Ann. Agric. Environ. Med. 13, 81-86.

MATKOVIĆ, K., M. VUČEMILO, B. VINKOVIĆ (2012): Dust and endotoxin in laying hen dwellings. Turk. J. Vet. Anim. Sci. 36, 189-195.

MATKOVIĆ, K., M. VUČEMILO, B. VINKOVIĆ, B. ŠEOL, Ž. PAVIČIĆ, A. TOFANT, S. MATKOVIĆ (2006): Effect of microclimate on bacterial count and airborne emission from dairy barns on the environment. Ann. Agric. Environ. Med. 13, 349-354.

MATKOVIĆ, K., M. VUČEMILO, I. ŠTOKOVIĆ, R. ŠIMIĆ, D. MARUŠIĆ, B. VINKOVIĆ, S. MATKOVIĆ (2013): Concentrations of airborne bacteria and fungi in a livestock building with caged laying hens. Vet. Arhiv. 83, 413-424.

NIELSEN, B. H., N. O. BREUM (1995): Exposure to air contaminants in chicken catching. Am. Ind. Hyg. Assoc. J. 56, 804-808.

OSTOVIĆ, M., Ž. PAVIČIĆ, A. TOFANT, T. BALENOVIĆ, A. EKERT KABALIN, S. MENČIK, B. ANTUNOVIĆ (2009): Airborne dust distribution in a farrowing pen in dependence of other microclimatic parameters during spring-summer period. Ital. J. Anim. Sci. 8, Suppl. 3, 196-198.

PRESTER, LJ., J. MACAN, K. MATKOVIĆ, M. VUČEMILO (2010): Determination of Aspergillus fumigatus allergen 1 in poultry farms using the enzyme immunoassay. Arh. Hig. Rada Toksikol. 61, 167-172.

RYLANDER, R. (2002): Endotoxin in the environment - exposure and effects. J. Endotoxin Res. $8,241-252$.

SALEH, M., J. SEEDORF, J. HARTUNG (2007): Inhalable and respirable dust, bacteria and endotoxins in the air of poultry houses. Proceedings of the International Conference DustConf 2007: How to improve air quality, 23-24 April, Maastricht, The Netherlands, CD rom.

SCHIERL, R., A. HEISSE, U. EGGER, F. SCHNEIDER, R. EICHELSER, S. NESSER, D. NOWAK (2007): Endotoxin concentration in modern animal houses in southern Bavaria. Ann. Agric. Environ. Med. 14, 129-136.

SEEDORF, J. (2004): Potential of emitable airborne endotoxin concentrations in an aviary and a caged husbandry for laying hens. Proceedings of the In-between Congress of the International Society for Animal Hygiene (ISAH), 11-13 October, Saint Malo, France, pp. 209-210. 
K. Matković et al.: Airborne dust and endotoxins in poultry house

SEEDORF, J., J. HARTUNG (2002): Dust and microorganisms in animal husbandry systems. Association for Technology and Structures in Agriculture, Darmstadt, KTBL-Schrift 393, 166 p. [in German]

SIMPSON, J. C., R. M. NIVEN, C. A. PICKERING, L. A. OLDHAM, A. M. FLETCHER, H. C. FRANCIS (1999): Comparative personal exposures to organic dusts and endotoxin. Ann. Occup. Hyg. 43, 107-115.

VARNAI, V. M., J. MACAN, D. PLAVEC, D. JUREŠA (2004): Endotoxin measurement in house dust using the end-point Limulus amebocyte lysate method. Arh. Hig. Rada Toksikol. 55, 175181.

VIEGAS, S., V. M. FAÍSCA, H. DIAS, A. CLÉRIGO, E. CAROLINO, C. VIEGAS (2013): Occupational exposure to poultry dust and effects on the respiratory system in workers. J. Toxicol. Environ. Health A. 76, 230-239.

VUČEMILO, M., B. VINKOVIĆ, K. MATKOVIĆ, R. BREZAK (2007): Hygienic air quality in poultry houses for consumer egg laying hens. Krmiva. 49, 89-94. [in Croatian]

VUČEMILO, M., K. MATKOVIĆ, B. VINKOVIĆ, J. MACAN, V. M. VARNAI, LJ. PRESTER, K. GRANIĆ, T. ORCT (2008): Effect of microclimate on the airborne dust and endotoxin concentration in a broiler house. Czech J. Anim. Sci. 53, 83-89.

WHYTE, P., J. D. COLLINS, K. McGILL, C. MONAHAN, H. O’MAHONY (2001): Distribution and prevalence of airborne microorganisms in three commercial poultry processing plants. J. Food Prot. 64, 388-391.

WHYTE, R. T. (2002): Occupational exposure of poultry stockmen in current barn systems for egg production in the United Kingdom. Br. Poult. Sci. 43, 364-373.

Received: 13 May 2016

Accepted: 22 December 2016

MATKOVIĆ, K., LJ. PRESTER, T. ORCT, J. MACAN, V M VARNAI, D. MARUŠIĆ, MARIO OSTOVIĆ, Ž. PAVIČIĆ, M. VUČEMILO: Utjecaj godišnjeg doba na koncentraciju prašine i endotoksina u zraku nastambe za kokoši nesilice. Vet. arhiv 87, 597-605, 2017.

\section{SAŽETAK}

U ovom radu istraživana je kvaliteta zraka u nastambi kavezno držanih kokoši nesilica u svim godišnjim dobima utvrđivanjem koncentracije prašine i endotoksina. Mjerenja su provođena dva puta na mjesec tijekom jednogodišnjeg proizvodnog ciklusa. Srednje vrijednosti koncentracije prašine i endotoksina kretale su se od $0,60 \mathrm{mg} / \mathrm{m}^{3}$ (svibanj) do $2,83 \mathrm{mg} / \mathrm{m}^{3}$ (studeni), odnosno od 203,15 EU/m $/ \mathrm{m}^{3}$ (kolovoz) do 745,53 EU/m $/ \mathrm{m}^{3}$ (travanj). Značajno veće koncentracije prašine i endotoksina u peradarniku ustanovljene su ujesen i zimi, endotoksini također i u proljeće, u usporedbi s ljetom ( $\mathrm{P}<0,05 \mathrm{sve})$. Iz rezultata istraživanja može se zaključiti da hladnija razdoblja godine predstavljaju veći rizik za dobrobit i proizvodnost kokoši nesilica, ali i za zdravlje zaposlenika u ovim nastambama s obzirom na koncentraciju prašine i endotoksina u zraku.

Ključne riječi: kvaliteta zraka, prašina, endotoksini, perad, godišnje doba 
